\title{
Using SWMM as a Tool for Floodplain Management in Ungauged Urban Watershed
}

\section{S. S. Wanniarachchi and N. T. S. Wijesekera}

\begin{abstract}
Mathematical modelling is a powerful tool for arriving at best water resources management. But it is necessary to possess gauged data for model calibration and verification. However most of the urban watersheds are not gauged and does not have high resolution terrain data when designing drainage infrastructure. There are many tools for urban stormwater modelling, but out of limited free tools, EPA SWMM5 has a good record of applicability in many locations elsewhere.
\end{abstract}

The present work shows the applicability of SWMM5 for an urban land extent in the Matara Municipal Council area which is ungauged. This study used literature reported values and data collected during field visits to runoff modeling to obtain order of magnitude values with easy comparison of engineering alternatives for stormwater management. It is thought that possibility of using a systematic and extensive data collection program for parameter identification using simple field measurements and engineering judgment together with stakeholder information for historical record verification provides opportunity to initiate structured and solution oriented data collection programs and modelling.

Kotuwegoda area with land extent of $0.475 \mathrm{~km}^{2}$ and 22 subcatchments draining via 8 outlets was modeled for a single event. It was identified that the most sensitive parameter is channel roughness and that engineering options by means of changing channel roughness and incorporating detention storages, could reduce the peak flow by approximately $30 \%$

Keywords: Ungauged, Floodplain management, SWMM5, Urban storm water, Mathematical modelling

\section{Introduction}

Water is a prime requirement for the existence of life however uncontrollable amounts of water can adversely affect the survival of living beings. In a tropical country like Sri Lanka, major water source is monsoonal rains. With significant rainfall in monsoon seasons, floods are very common. In the wet zone, frequency of flooding is in the range of two to three floods per annum. Floods not only lead to economic losses but also result in loss of human lives and this is considerably affected when the urban watersheds are flooded. Mathematical modelling of watersheds is a popular approach followed by engineers to identify solutions for flood problems [1]. Mathematical modelling of watersheds requires a suitable model for the representation of the phenomena that needs to be analysed, requires data for calibration and verification of the model outputs and sufficient resources both physical and financial for acquisition of the data and the model. In this context the best option for engineers would be to seek a model that is adequately detailed in describing the processes, sufficiently representing the extents, suitability, simple for data collection, spending the least amount of time, providing sufficiently accurate outputs which serve the purpose and affordable to available budgets.

The EPA Storm Water Management Model (SWMM5) is a dynamic rainfall-runoff simulation model first developed in 1971 and used for single event or long-term (continuous) simulation of runoff quantity and quality from primarily urban areas. The runoff component of SWMM5 operates on a collection of subcatchment areas that receive precipitation and generate runoff and pollutant loads. The routing portion of SWMM5 transports this runoff through a system of pipes, channels, storage/treatment devices, pumps, and regulators. SWMM tracks the quantity and quality of runoff generated within each

S.S. Wanniarachchi, B.Sc. Eng. (Moratuwa), Research Assistant, Department of Civil Engineering, University of Moratuwa, Sri Lanka

Eng. (Prof.) N.T.S.Wijesekera, C. Eng., FIE(Sri Lanka),

B.Sc. Eng. (Sri Lanka), M. Eng. (Tokyo), D. Eng. (Tokyo),

Professor of Civil Engineering, Department of Civil

Engineering, University of Moratuwa, Sri Lanka 
subcatchment, and the flow rate, flow depth, and quality of water in each pipe and channel during a simulation period comprised of multiple time steps. This model is available for free download and use. [2]

Literature surveys reveal many applications in the USA and in several parts of the world [3] but there are no applications for Sri Lanka.

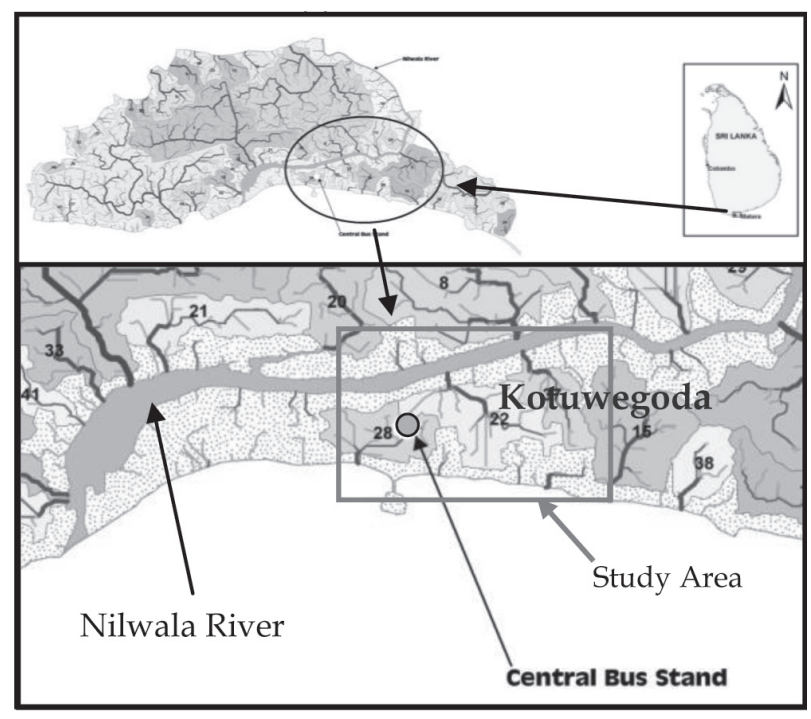

from the selected area. The present case study is also intended to explore this potential of SWMM model.

\section{Study Area}

Kotuwegoda-Browns hill area in the Matara Municipal Council is located near the mouth of Nilwala River (Figure 1). Drainage area selected for the study contains eight smaller drainage canals. Out of them six are draining to the Nilwala River while two are draining to the Sea (Figure 2). The study area is ungauged, has an approximate extent of $0.475 \mathrm{~km}^{2}$, and bounded by Nilwala River in North, Indian Ocean in South and Browns hill mountainous area in the East. Most of the area is flat terrain, except Browns hill, where the peaks and ridges rise above 45.0 MSL contour.

Kotuwegoda area is a substantially populated area and also possesses a high commercial value being close to the coast, the playground and the park, central bus stand, shopping complexes and cinema.

Figure 1 - Location of Study Area

This could be because there is significant data need due to the Model's capability to handle spatially distributed computations and also the need of good data for model calibration and verification. In Sri Lanka there are very few urban watersheds with gauged stream flows. However considering the advantages that are evident if the model can be applied satisfactorily, the present work is undertaken to study the control parameters and potential of EPA SWMM model for urban watersheds in Sri Lanka.

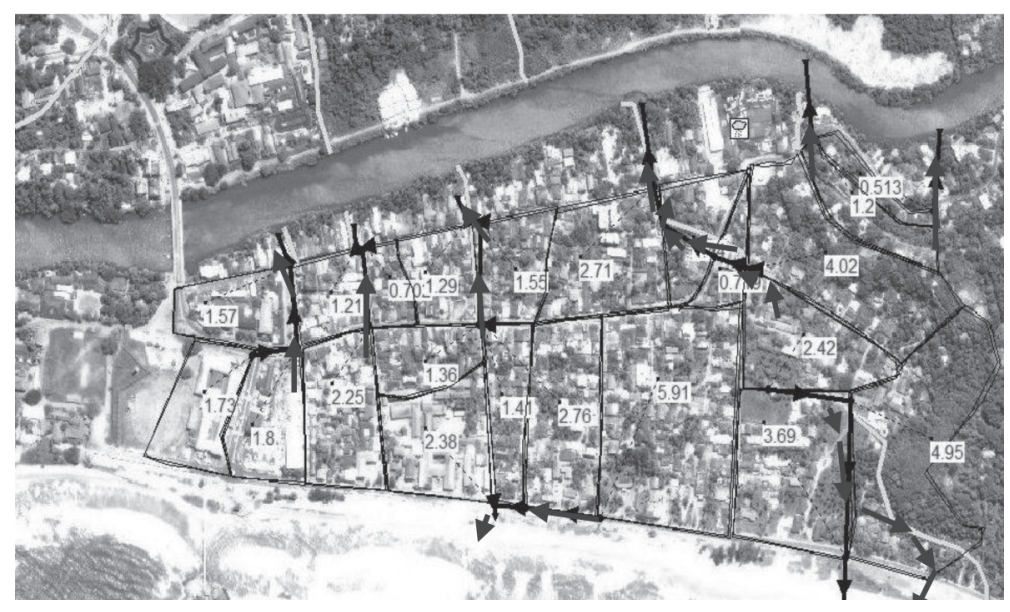

Figure 2 - Satellite Image of Kotuwegoda

\section{Objective}

The objective of the present work is to apply the SWMM urban stormwater management mathematical model for ungauged urban watershed and check the effect of the control parameter values for urban flooding.

In watershed modelling though the most common approach and the techniques facilitate the analysis of either an entire watershed or its sub-watersheds directing stormwater to a single outlet, the SWMM enable modelling of several watersheds leading to several outlets

\section{Methodology}

Several published and unpublished studies on Catchment, Flood and Flood Plain Characteristics, Flood Plain Management Methods, Runoff Calculation Methods and Mathematical Modelling Relative to Urban Stormwater Management were utilised to obtain information regarding the issues and alternatives with respect to mathematical modelling of stormwater [4][5][6] 
Available data from already published reports and collection agencies were collected in order to obtain flood, terrain and hydrologic characteristics of the study area [7]. It was noted that other than regional rainfall and catchment characteristics there were no hydraulic or hydrologic data pertaining to the study area. Desk studies were carried out using available Satellite Images on Internet and the $1: 10,000$ topographic maps of the survey department prepared in 2002 to capture drainage directions, land use and other physical infrastructure for the preparation of the watershed schematic diagram and for the identification of the Nodes for the model (Figure 3).

Sub catchments and the canals for the model schematic were demarcated using a GIS tool and areas and channel lengths etc., were computed by GIS. digital photographs, tape measurements and handheld GPS units. A drainage area stakeholder survey through interview type discussions was used to capture the historical flood information pertaining to the study area. Flood elevations indicated by the villagers on permanent or semi permanent structures were captured to the closest half a feet. Ponded areas at each node of the channel network, flood marks on the structures and trees, flow path during floods were assessed by the information from the stakeholders.

The SWMM model developed with collected data was used to generate flood situation for a known rainfall event and other anticipated scenario for model evaluation and for proposing methods for flood management in the study area [8].

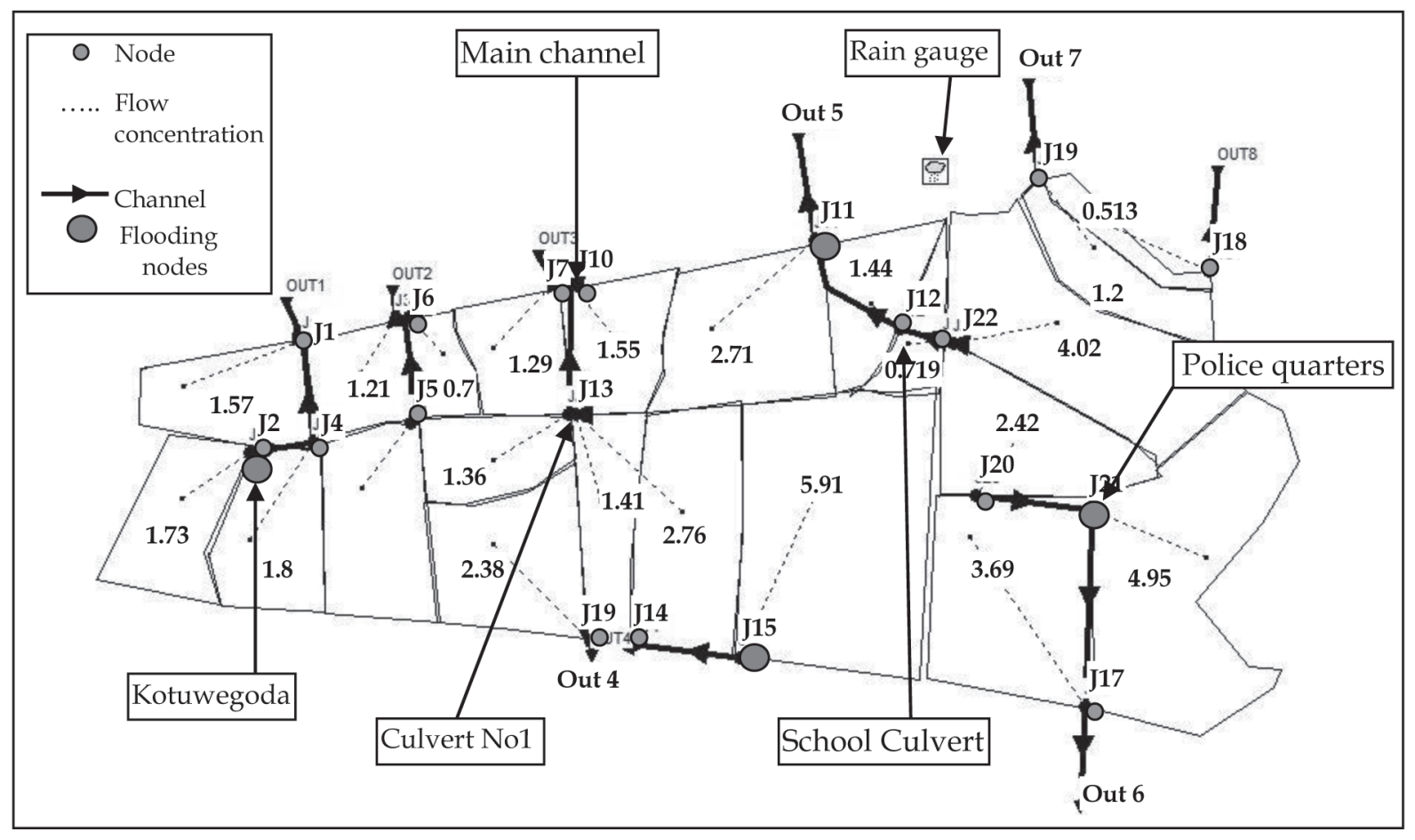

Figure 3 - Schematic diagram of the Model

Several field visits were undertaken to confirm the desk study results and also to capture information about the channel network and characteristics, flooding details, to select parameters from guideline tables on runoff and roughness coefficients, flow conditions and velocities, soil types and vegetation patterns etc. Due to time and other resource limitations, no engineering surveys or detailed parameter measurements were carried out as part of the field work program. During the field work, estimation of characteristics was done with
Unfortunately there were no tidal records in southern coast close to Nilwala River, and then according to the Colombo tidal level variation records [9] modelling incorporated a Tidal control condition at the outfalls of the canals. Then the flows were controlled by the inflows and the tidal variation of sea. In this assessment no backwater effects were assumed to occur due to river flows. Heights for the channel inverts and outfalls were given relative to surface of the closest road level. Spot heights of 
the roads were available with the 1:10,000 topographic maps.

\section{Data Collection and Data}

At the Kotuwegoda-Browns hill area there are eight major stormwater channels. Major soil type in the area was observed as Clayey Sand. The SWMM requires to first establish the schematic of the drainage area. The major parameters required by the model are the Sub catchments, canal network and the junction details, channel and conduit details, the rain gauge and outfall locations. Field survey interviews were structured to capture the specific information for the modelling specially the drainage direction. Table 1 shows the objectives pertaining to the questions asked during the field visits.

Measured rainfall recorded at Thudawa Pump House and Kekanadura in three hour intervals were collected from the Department of Irrigation (Table 2).

\section{Table 1 - Key Aspects of Questionnaire Survey}

\begin{tabular}{|l|l|}
\hline \multicolumn{1}{|c|}{$\begin{array}{c}\text { Question for } \\
\text { Stakeholders }\end{array}$} & \multicolumn{1}{c|}{ Objective } \\
\hline $\begin{array}{l}\text { Flooded area at } \\
\text { the Nodes }\end{array}$ & $\begin{array}{l}\text { Model input: the } \\
\text { flooded area at the } \\
\text { node locations }\end{array}$ \\
\hline $\begin{array}{l}\text { Flood levels at } \\
\text { Nodes }\end{array}$ & $\begin{array}{l}\text { Acceptability of model } \\
\text { outputs, adequacy of } \\
\text { model calibration and } \\
\text { verification }\end{array}$ \\
\hline $\begin{array}{l}\text { Inundation } \\
\text { Duration }\end{array}$ & $\begin{array}{l}\text { Drainage condition of } \\
\text { channel, slopes, } \\
\text { obstructions etc. }\end{array}$ \\
\hline $\begin{array}{l}\text { Flood Inundation } \\
\text { area }\end{array}$ & Identify the flood plain \\
\hline $\begin{array}{l}\text { Water level } \\
\text { variation of the } \\
\text { channels during } \\
\text { Rainfall }\end{array}$ & $\begin{array}{l}\text { Time of concentration } \\
\text { and flood condition } \\
\text { verification }\end{array}$ \\
\hline $\begin{array}{l}\text { Frequency of } \\
\text { flooding }\end{array}$ & $\begin{array}{l}\text { Identify the severity of } \\
\text { events taken for } \\
\text { modelling }\end{array}$ \\
\hline
\end{tabular}

Catchment physical parameters and the flood data at nodes captured during the stakeholder interviews at the field visits are shown in the Table 3. The schematic for the model was developed using data identified both from field and desk studies (Figure 3). The drainage canals sections were given numbers from $\mathrm{C} 1$ to
C22 and the Nodes were given Numbers from $\mathrm{J} 1$ to $\mathrm{J} 22$.

\section{Model Application}

The Kotuwegoda study area was satisfactorily represented in the SWMM incorporating the canal schematic, node and other physical parameters such as roughness, section dimensions, slopes, lengths etc. It was indicated that the model could compute the water elevations in the canal network and nodes, discharges etc and indicate flooding nodes as well.

The model consisted of $22 \mathrm{sub}$ catchments with the largest having an area of $0.05 \mathrm{~km}^{2}$ (Figure 3) Total length of drainage channels were $2.924 \mathrm{~km}$ and the study area had an average ground slope of 0.0063 .

Table 2 - Rainfall Event Obtained from the Irrigation Department

\begin{tabular}{|c|c|c|c|c|}
\hline Year & Month & Date & Time & $\begin{array}{l}\text { Rainfall } \\
(\mathrm{mm})\end{array}$ \\
\hline \multirow{8}{*}{2009} & \multirow{8}{*}{11} & \multirow{8}{*}{5} & 12noon & 5.5 \\
\hline & & & $3 \mathrm{pm}$ & 12.3 \\
\hline & & & $6 \mathrm{pm}$ & 4.3 \\
\hline & & & $9 \mathrm{pm}$ & 6.4 \\
\hline & & & $12 \mathrm{pm}$ & 10 \\
\hline & & & $3 \mathrm{am}$ & 15 \\
\hline & & & 6am & 15 \\
\hline & & & 9am & 10.2 \\
\hline
\end{tabular}

A set of parameters were selected as initial values for the model and the generated outputs were observed for the indication of flooding as mentioned by the stakeholders. Since the flood information collected was not exact measurements but were stakeholder estimates which were relative to ground levels, and was of a single event, model calibration was limited to this event. The channel surface roughness and the soil infiltration parameters were changed while observing the flooding conditions at nodes to fall within the upper and lower limits reported by the stakeholders. Mass balance calculations indicated that a total of 32,640 cubic meters have been received by the project area on the 05 Nov 2009 and the outflows from all the streams as runoff had been 20,340 (62.32\%) cubic meters. Average runoff coefficient of the catchment is 0.623 . The balance has been infiltrated $(34.16 \%)$ or stored as surface detention (3.52\%). Infiltration soil parameters are shown in Table 4. According to 
node flooding summary of SWMM, most critical nodes based on inundation height were identified. Ponded areas at the nodes were identified at the field, and approximated that area in to rectangular storage units in the model. Conversion of the flood volume in to flood height was done by means of that. The nodes and associated values are indicated in the Table 5. Model input parameters were changed while observing the flooding to capture the parameter sensitivities. Results indicated that channel roughness is the most sensitive with model output quantities at the nodes changing by $30 \%$ with the change of $40 \%$. Channel width was identified as the least sensitive with model output quantities changing by $6.4 \%$ with the change of $30 \%$ while reproducing the node outputs.

Outflow hydrograph at the nodes (Table 5) for the rainfall input 05 Nov 2009 is shown in Figure 4. Figure 5 indicates a typical longitudinal section of a canal with the water surface profile showing the potential of capturing dynamic water surface profile and easy identification of node and channel overtopping. Effect of the channel slope and the channel depth for the overtopping can be identified through the water surface profile.
Table 4 - Soil Characteristics

\begin{tabular}{|l|c|c|}
\hline $\begin{array}{l}\text { Saturated } \\
\text { hydraulic } \\
\text { conductivity }\end{array}$ & K & $29.97(\mathrm{~mm} / \mathrm{hr})$ \\
\hline $\begin{array}{l}\text { Suction } \\
\text { head }\end{array}$ & $\boldsymbol{\Psi}$ & $60.96(\mathrm{~mm})$ \\
\hline Porosity & $\boldsymbol{\phi}$ & 0.437 (fraction) \\
\hline $\begin{array}{l}\text { Field } \\
\text { capacity }\end{array}$ & FC & 0.105 (fraction) \\
\hline $\begin{array}{l}\text { Wilting } \\
\text { Point }\end{array}$ & WP & 0.047 (fraction) \\
\hline
\end{tabular}

Table 5-Flood levels Obtain by the Model

\begin{tabular}{|c|c|c|}
\hline Node & $\begin{array}{l}\text { Average } \\
\text { Flood } \\
\text { Level (m) }\end{array}$ & \% Error \\
\hline J2 & 0.36 & -20 \\
\hline J8 & 0.4 & -33.3 \\
\hline J11 & 0.8 & -25 \\
\hline J15 & 0.35 & -16.7 \\
\hline J21 & 0.34 & 24.4 \\
\hline
\end{tabular}

Table 3 - Collected data from Field Visits

\begin{tabular}{|l|c|c|c|c|l|l|l|c|}
\hline \multirow{2}{*}{$\begin{array}{c}\text { Location } \\
\text { Identification }\end{array}$} & \multicolumn{3}{|c|}{ Conduit Geometry } & $\begin{array}{c}\text { Geometry } \\
\text { of the } \\
\text { Nodes }\end{array}$ & \multicolumn{2}{c|}{ Channel surface condition } & $\begin{array}{c}\text { Flood } \\
\text { depth } \\
\text { (m) }\end{array}$ \\
\cline { 2 - 9 } & Shape & $\begin{array}{c}\text { Average } \\
\text { Depth } \\
\text { (m) }\end{array}$ & $\begin{array}{c}\text { Top } \\
\text { Width } \\
(\mathbf{m})\end{array}$ & $\begin{array}{c}\text { Invert EL } \\
\text { (m MSL) }\end{array}$ & Left Bank & $\begin{array}{c}\text { Right } \\
\text { Bank }\end{array}$ & Bed \\
\hline $\begin{array}{l}\text { Kotuwegoda } \\
\text { (J2) }\end{array}$ & Rectangular & 0.5 & 0.85 & 1.6 & Concrete & Concrete & Sediments & 0.3 \\
\hline $\begin{array}{l}\text { Culvert No 1 } \\
\text { (J8) }\end{array}$ & Rectangular & 0.8 & 0.55 & 1.3 & Concrete & Concrete & Muddy & 0.3 \\
\hline Main canal & Rectangular & 0.8 & 2 & 1 & Concrete & Concrete & Concrete & 0.3 \\
\hline River out 1 & Rectangular & 0.8 & 1.5 & 0.3 & Vegetation & Vegetation & Sediments & 0.3 \\
\hline $\begin{array}{l}\text { School } \\
\text { Culvert (J11) }\end{array}$ & Trapezoidal & 0.7 & 0.9 & 1 & Vegetation & Masonry & Muddy & 0.6 \\
\hline $\begin{array}{l}\text { Police } \\
\text { quarters (J21) }\end{array}$ & Rectangular & 0.6 & 0.45 & 1.15 & Vegetation & Vegetation & Sediments & 0.45 \\
\hline $\begin{array}{l}\text { Peakwella } \\
\text { canal }\end{array}$ & Rectangular & 0.2 & 1 & 1.2 & Concrete & Concrete & Concrete & 0.3 \\
\hline River out 2 & Rectangular & 0.7 & 1 & 0.45 & Vegetation & Vegetation & Muddy & 0 \\
\hline Sea outfall & Parabolic & 1 & 1.7 & 0.2 & Vegetation & Vegetation & Sand & 0 \\
\hline
\end{tabular}




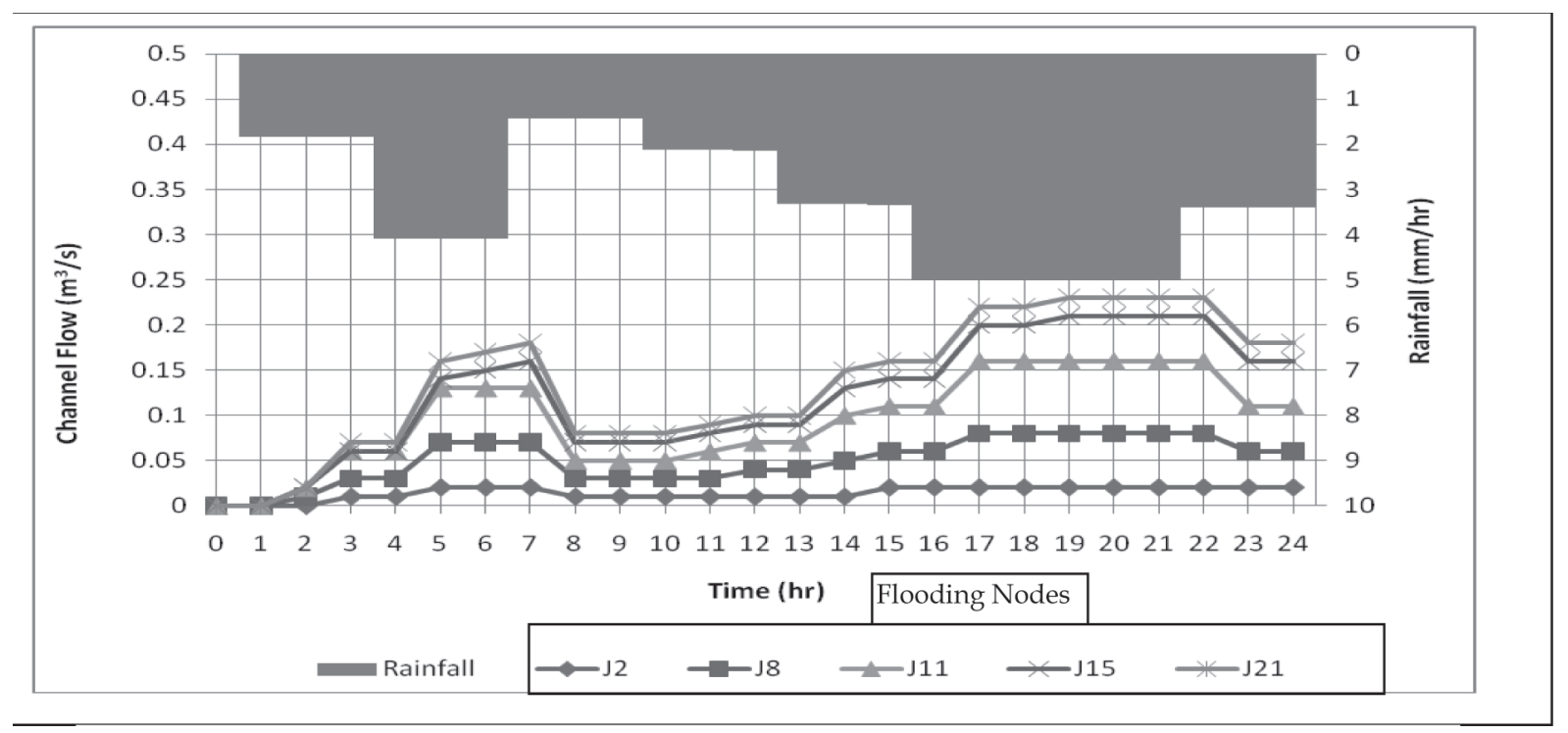

Figure 4- Outflow Hydrograph at the Flooding Nodes

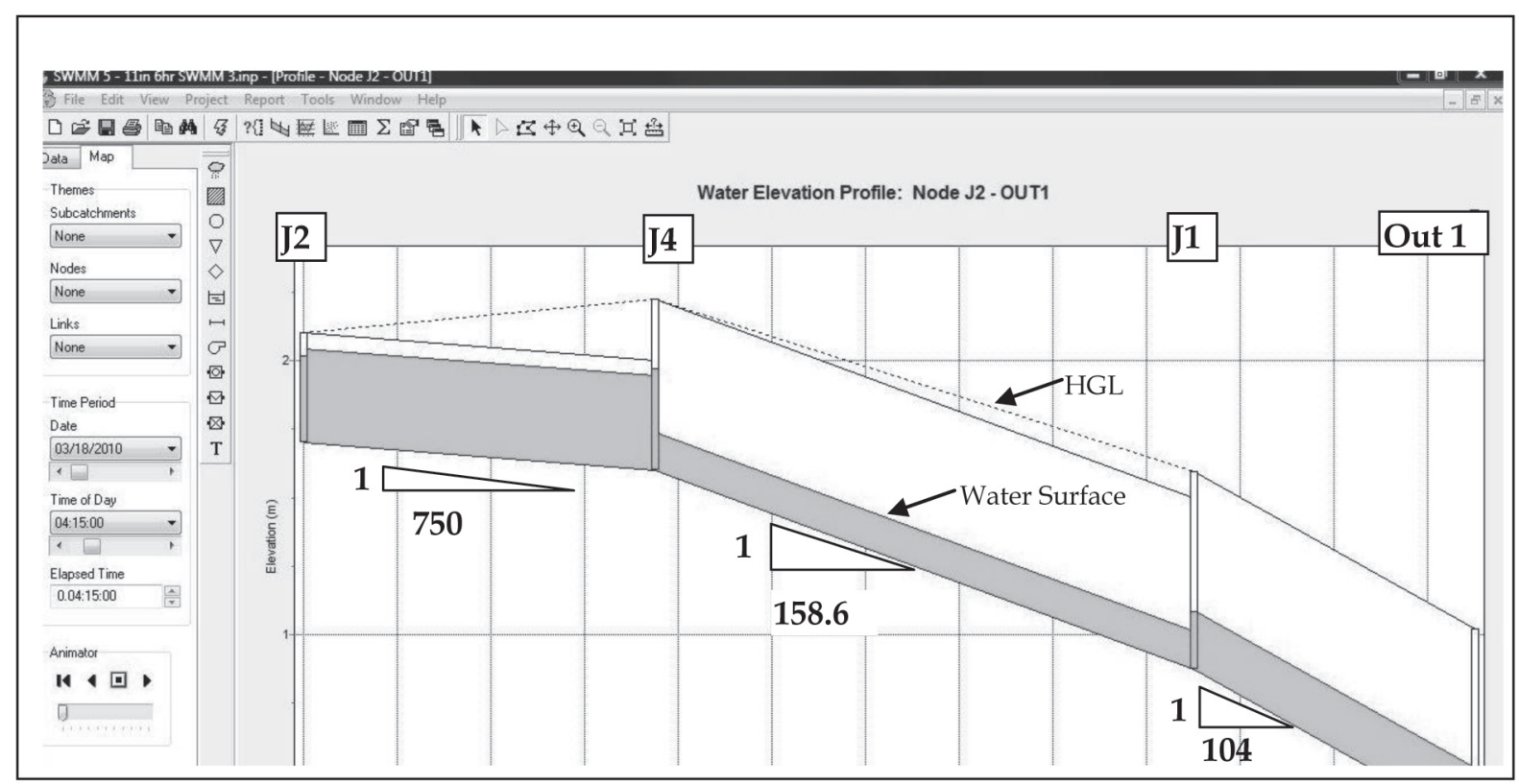

Figure 5 - Water Surface Profile of Channel 1: Node J2- Outfall 1

\section{Option Identification}

Being a commercial area, Kotuwegoda has only a few land areas that could be used for flood retention. Also due to rapid urbanization the percentage area becomes paved at a very rapid rate. Any engineering interventions for flood mitigation need to consider the economic values while taking the public inconvenience and health issues also into account.

Therefore engineering option selection need to be done while attempting to identify the least cost options and for this SWMM provides a good opportunity with the possibility of incorporating spatial variation of parameters and enabling dynamic viewing of outputs through animations. Most of the channels were silted, vegetated and drainage was obstructed by human interventions. Many canal reservations were occupied by people with their dwelling units.

As a solution for the reduction of flooding at each node, an attempt was taken to reduce the canal roughness so that water could be easily drained from the node. Where possible, storages for ponding at the nodes were enhanced to explore the possibility of peak flow attenuation.

The drainage improvement and detention options improved the outflow hydrographs of each stream. The changes effected at selected 
nodes of streams in the Study area are shown in the Table 6.

Table 6 - Changes at selected Nodes

\begin{tabular}{|c|c|c|}
\hline Stream & Node & Engineering Solution \\
\hline $\begin{array}{c}\text { Channel } \\
1\end{array}$ & $\mathrm{~J} 2$ & $\begin{array}{c}\text { Storage Unit } \\
(4 \mathrm{~m} \times 5 \mathrm{~m} \times 1 \mathrm{~m})\end{array}$ \\
\hline $\begin{array}{c}\text { Channel } \\
3\end{array}$ & $\mathrm{~J} 8$ & $\begin{array}{c}\text { Canal lining, Introduce } \\
\text { silt traps and trash racks }\end{array}$ \\
\hline $\begin{array}{c}\text { Channel } \\
8\end{array}$ & $\mathrm{~J} 15$ & $\begin{array}{c}\text { Canal lining, Introduce } \\
\text { silt traps and trash racks }\end{array}$ \\
\hline $\begin{array}{c}\text { Channel } \\
4\end{array}$ & $\mathrm{~J} 11$ & $\begin{array}{c}\text { Concrete lining instead } \\
\text { of masonry }\end{array}$ \\
\hline
\end{tabular}

The Table 7 shows there are two nodes with little, for a very short duration, flooding after the incorporation of a reduction in the canal roughness from 0.025 to 0.015. Model roughness parameters are shown in Table 8.

Table 7 - Node Flooding Summary

\begin{tabular}{|c|c|c|}
\hline Node & $\begin{array}{l}\text { Maximum } \\
\text { Rate } \\
\left(\mathrm{m}^{3} / \mathrm{s}\right)\end{array}$ & $\begin{array}{l}\text { Total flood } \\
\text { volume } \\
\left(10^{6} \times \text { Liters }\right)\end{array}$ \\
\hline $\mathrm{J} 11$ & 0.24 & 1.005 \\
\hline $\mathrm{J} 14$ & 0.023 & 0.04 \\
\hline
\end{tabular}

Table 8 - Roughness Coefficients

\begin{tabular}{|c|c|c|}
\hline \multirow{2}{*}{$\begin{array}{c}\text { Surface } \\
\text { Condition }\end{array}$} & \multicolumn{2}{|c|}{ Roughness Coefficient } \\
\cline { 2 - 3 } & $\begin{array}{l}\text { Overland } \\
\text { flow }\end{array}$ & $\begin{array}{l}\text { Open } \\
\text { Channels }\end{array}$ \\
\hline Concrete & 0.012 & $0.011-0.02$ \\
\hline $\begin{array}{c}\text { Rubble or } \\
\text { riprap }\end{array}$ & 0.024 & $0.02-0.035$ \\
\hline Vegetal & 0.4 & $0.03-0.4$ \\
\hline $\begin{array}{c}\text { Earth, } \\
\text { winding }\end{array}$ & - & $0.025-0.04$ \\
\hline Grass & $0.15-0.24$ & - \\
\hline
\end{tabular}

\section{Discussion}

The free of charge SWMM5 model was identified as a user friendly, easily understandable powerful tool for urban watershed modelling and visualization of results. Backdrop image facility provided demarcation of a schematic in a physically more realistic manner while animated output capability can be considered an asset for practicing engineers. The following actions should be taken with caution when modelling urban floods using the SWMM.

Model requires a clear understanding of the infiltration and routing models for option selections without ambiguity. Enabling the input parameters such as pervious and impervious area, roughness values etc., the model provide sufficient capability to model the dynamism in urban area. It is also important to have high resolution terrain data for confidently converting the flood volumes to inundation heights.

With the demonstration of applicability it is now possible to initiate good data collection programs for urban watersheds which will ensure providing rational watershed management alternatives for relief of flood prone area stakeholders

\section{Conclusions}

1. SWMM also showed the capability to model several outfalls simultaneously, leading to a significant advantage of modelling a land extent of any shape

2. The present work clearly indicated the capability of model to visualize the outflows at nodes and channel sections together with animations which is a significant advantage when selecting options for flood mitigation

3. The present work showed that even in the absence of gauged flow data and high resolution terrain models, a reasonable modelling can be undertaken with well planned field work to arrive at order of magnitude solutions.

4. it was indicated that improving canal sections to less roughness values and introducing detention storages in Kotuwegoda Area would lead to an approximately $30 \%$ peak flow attenuation

5. The study indicated that the most sensitive parameter for the model is channel surface roughness and the least sensitive one is Channel width with sensitive values of $30 \%$ and $6.4 \%$ respectively. 


\section{References}

1. MHW New Zealand limited, New Zealand Guidelines for Integrated Stormwater Management, 2003-2004.

2. Urban watershed Management Research.2011, Stormwater Management Model (SWMM). Available from:http:/ / www.epa.gov/ednnrmrl/ models/swmm [Accessed 15 January 2011].

3. Nakamura, J., Villagra, N. Hydrologic Modelling of the Little Crum Creek Watershed with SWMM. Design Project Report, 2009,pp 15-46.

4. Lewis, A, Stormwater Management Model User's manual Version 5.0, U.S. Environmental Protection Agency, 2008.

5. Pivota, Jean-Marc, Josiena, Etienne and Martinb, Philippe.,2002/12/25. Farms Adaptation to Changes in Flood Risk: A Management Approach. Journal of Hydrology 267.

6. Maidment, D.R., Hand Book of Hydrology. $1^{\text {st }}$ ed. New York: McGraw Hill Book Company, 1993.
7. Wijesekera, N.T.S, Preparation of the Stormwater Drainage Plan for Matara Municipal Council Project Document, University of Moratuwa. (Unpublished), 2009.

8. Guo, Y, Hydrologic Design of Urban Flood Control Detention Ponds. Abstract, Journal of Hydrologic Engineering, 2001.

9. Wijeratne. E. M. S, Levelling of Sri Lanka Tide Gauges for Improved Hydrodynamic Modelling of the Palk Strait. Journal of Natural Aquatic Resources Research and Development Agency, 38, pp16-24, 2007.

10. Juraj M. Cunderlik, Taha B.M.J. Ouarda., Regional Flood-Rainfall DurationFrequency Modeling at Small Ungaged sites. Journal of Hydrology, 345, pp 61- 69, 2007.

11. Vidal, Jean-Philippe, Moisan, Sabine, Faure, Jean-Baptiste and Dartus, Denis., River Model Calibration, from Guidelines to Operational Support Tools. Environmental Modelling \& Software, 22., 2007. 